JERZY JANCZEWSKI

Akademia Humanistyczno-Ekonomiczna w Łodzi, Polska - University of Humanities and Economics in Lodz, Poland

\title{
Mikromobilność w systemie transportowym miasta
}

\section{Micromobility in the City Transport System}

Streszczenie: Mikromobilność to wykorzystywanie w systemie transportowym miast małych i lekkich środków transportu umożliwiających pokonywanie krótkich dystansów. Dzięki niewielkim gabarytom i małej masie ułatwiają one poruszanie się po wąskich i zatłoczonych odcinkach miast, a ich alternatywny napęd eliminuje hałas i redukuje tzw. ślad węglowy. Do środków tych zaliczają się m.in. rowery, hulajnogi, deskorolki, skutery, motorowery, a także małe, lekkie samochody (ang. microcar, quadricycle). Celem artykułu jest wyjaśnienie, czym jest mikromobilność, wskazanie jej miejsca i zastosowania w systemie transportowym miasta oraz zaprezentowanie stanu mikromobilności w Polsce. W realizacji tego celu przydatne były: analiza wybranej literatury przedmiotu i próbne badania $\mathrm{z}$ wykorzystaniem kwestionariusza ankietowego. W podsumowaniu zwrócono uwagę na duże zainteresowanie mikromobilnością i jej wpływem na obsługę pierwszego i ostatniego kilometra transportu w mieście, a także na liczne bariery związane z jej wdrażaniem. Zdaniem autora artykułu w postępie mikromobilności bardzo istotnymi zagadnieniami są rozbudowa tzw. niezmotoryzowanej infrastruktury, poszerzenie dostępności do niej, uzupełnianie, modyfikowanie i szybkie przyjmowanie stosownych uregulowań prawnych, opracowanie standardów bezpieczeństwa, homologowanie urządzeń mikromobilności oraz kontrolowanie i nadzór nad tymi urządzeniami w ruchu.

\begin{abstract}
Micromobility uses small and light means of transport in the city transport system to cover short distances. Due to their small size and low weight, these measures facilitate movement in narrow and crowded sections of cities, and their alternative drive eliminates noise and reduces the so-called carbon footprint. They include, among others, bicycles, scooters, skateboards, mopeds and also small light cars (microcar, quadricycle). The purpose of the article is to explain what micromobility is, to indicate its place and application in the city transport system and to present micromobility in Poland. In achieving the goal, an analysis of the selected literature on the subject and a test research using a questionnaire proved useful. In the summary, attention was drawn to the great interest in micromobility and its impact on the service of the first and last kilometre of transport in the city, as well as to numerous barriers related to its implementation. According to the author of the article, in the progress of micromobility, a very important issue is the expansion of the so-called non-motorised infrastructure, expanding accessibility to it, supplementing, modifying and quickly adopting relevant legal regulations, developing safety standards, approving micromobility devices, as well as controlling and supervising these devices in motion.
\end{abstract}


Słowa kluczowe: elektromobilność; hulajnogi elektryczne; mikromobilność; system transportowy; środki transportu mikromobilności

Keywords: electric scooters; electromobility; micromobility; micromobility of transport measures; transport system

Otrzymano: 28 sierpnia 2019

Received: 28 sierpnia 2019

Zaakceptowano: 10 marca 2020

Accepted: 10 March 2020

Sugerowana cytacja/Suggested citation:

Janczewski, J. (2020). Mikromobilność w systemie transportowym miasta. Przedsiębiorczość Edukacja [Entrepreneurship - Education], 16(1), 257-274. doi: 10.24917/20833296.161.21

\section{Wstęp}

Mobilność utożsamiana z samochodem osobowym, choć w Polsce jeszcze ciągle popularna, może być w niedalekiej przyszłości zupełnie nieaktualna, a sposoby przemieszczania się osób mogą być zupełnie odmienne od obecnych (Kauf, 2016a). Mobilność czeka szybka ewolucja podobna do ewolucji w komunikacji lub handlu detalicznym (Mobility 2040..., 2016: 9), gdyż obecne modele biznesowe mobilności, zwłaszcza w miastach, jak zauważa J. Szołtysek, są źródłem licznych konfliktów (Szołtysek, 2018), natomiast systemy mikromobilności mogą być pomocne w łagodzeniu tych konfliktów.

Dyskurs o wykorzystaniu mikromobilności jest aktualny, a w dalszej perspektywie powinien być rozszerzony rozważaniami o zmianach zasad zarządzania łańcuchami dostaw w miastach i zmianach ich dotychczasowych modeli biznesowych, szczególnie w pierwszej i ostatniej fazie podróży (pierwsza i ostatnia mila). Konieczne są też stosowne regulacje prawne odpowiadające rozwojowi nowych technologii. Póki co nie ma dowodów na to, że mikromobilność prowadzi do zmniejszenia liczby samochodów w miastach, brakuje też odpowiedzi na pytanie, czy takie trendy mikromobilności jak elektryczne rowery, hulajnogi lub skutery wpływają na ograniczenie przejazdów samochodami.

Celem niniejszego artykułu jest wyjaśnienie, czym jest mikromobilność, wskazanie jej miejsca i zastosowania w systemie transportowym miasta oraz przedstawienie stanu mikromobilności w Polsce. W artykule przytoczono również wstępne badania własne mające na celu rozpoznanie, jakie transportowe środki mikromobilności są najczęściej używane, czy mogą one mieć wpływ na ograniczenie negatywnych skutków transportu samochodowego w miastach, a także, czy elektryczne hulajnogi i podobne e-urządzenia powinny mieć dostęp do infrastruktury rowerowej. Do realizacji tego celu wykorzystano analizę wybranej literatury przedmiotu i próbne badania z wykorzystaniem kwestionariusza ankietowego. Najważniejsze wnioski przedstawiono w zakończeniu tekstu.

\section{Mikromobilność - definiowanie}

Mikromobilność to koncepcja zakładająca wykorzystywanie w rozwiązaniach komunikacyjnych niewielkich i lekkich pojazdów silnikowych oraz urządzeń powolnego transportu, umożliwiających pokonywanie krótkich dystansów - najczęściej pierwszego lub ostatniego odcinka zaplanowanej podróży. Dzięki niewielkim gabarytom i małej masie ułatwiają 
one poruszanie się po wąskich i zatłoczonych odcinkach miast, a ich alternatywny napęd eliminuje hałas i redukuje tzw. ślad węglowy. Do środków tych zaliczają się m.in. rowery, hulajnogi, deskorolki, skutery, motorowery, a także małe, lekkie samochody (ang. microcar, quadricycle). Punktem przełomowym dla wyróżnienia terminu „mikromobilność” było rozpowszechnienie się elektromobilności (e-mobilności) przez upowszechnianie $\mathrm{w}$ indywidualnych środkach transportu napędów elektrycznych, co wynikało również z potrzeb konsumentów, którzy coraz chętniej wybierają rozwiązania oparte na e-mobilności (Nowicka, 2017). Należy zauważyć, że technologie wykorzystywane w e-mobilności stają się ostatnio bardzo popularne i coraz bardziej widoczne, a tym samym i destrukcyjne dla technologii konwencjonalnych (Budzik, 2019).

Poszukując źródeł definicji mikromobilności, warto nawiązać do znanych i powszechnie używanych pojęć mobilności i elektromobilności. Mobilność, choć charakteryzuje się wieloma kategoriami, to $\mathrm{w}$ aspekcie przemieszczania się osób i ładunków zwykle kojarzy się z ruchem i dynamiką, zaś elektromobilność dotyczy zaspokajania potrzeb w zakresie mobilności w aspekcie zrównoważonego rozwoju z wykorzystaniem napędu elektrycznego i przenośnych zasobników energii elektrycznej (akumulatorów) (Scheurenbrand i in., 2015).

W literaturze dotyczącej transportu i logistyki pojęcie mikromobilności pojawiło się na początku ubiegłej dekady i związane było z użyciem tzw. urządzeń transportu osobistego (UTO), wspomagających przemieszczanie się na krótkich odcinkach i usprawniających transport w pierwszym i ostatnim kilometrze podróży. Niektóre z tych urządzeń znano i wykorzystywano od dawna, np. stosowały je osoby niepełnosprawne o ograniczonej mobilności (patrz: Philpott, 2013: 16-19). Pospolity rower od momentu opatentowania w 1818 r. jego pierwowzoru, tzw. maszyny biegowej (drezyny), liczy 202 lata (Historia roweru..., 2019) i doczekał się wielu zastosowań. Podobnie długą historię i wiele rozwiązań mają rowery towarowe również i hulajnogi.

Termin „mikromobilność” nie ma jednoznacznej definicji. Formułowana jest ona dla konkretnych warunków, a jej zakres dotyczy potrzeb badaczy lub zainteresowanych instytucji. Na przykład NCL (National Leaque of Cities) kojarzy mikromobilność z masowym współużytkowaniem rowerów i skuterów w miastach i przeciwstawia ją stosowanemu przez Departament Transportu USA pojęciu mikrotranzytu (Micromobility in Cities..., 2019).

Inspirujące rozważania na temat definiowania pojęcia mikromobilności można odnaleźć w opracowaniu H. Dediu (Dediu, 2019). Autor ten uważa, że mikromobilność powinna zapewniać możliwie najwyższą niezależność w przemieszczaniu się, a jej środki powinny zużywać minimalną ilość energii. Według Dediu, mikromobilność to system indywidualnego transportu w mieście z użyciem środków transportu przeważnie z napędem elektrycznym, ważących nie więcej niż $500 \mathrm{~kg}$ (Bruce, 2018). Mikromobilność może zatem odnosić się zarówno do urządzeń/środków osobistej mobilności/transportu (PMD - ang. Personal Mobility Device, MMD - Motorised Mobility Devices, PAMD - Personal Assitive Mobility Device, PLEV - Personal Light Electric Vehicles, UTO - urządzenia transportu osobistego), jak również do inteligentnej mobilności (Shin, Lee, Park, 2018) oraz do skuterów, motorowerów i mikrosamochodów.

W Polsce termin „mikromobilność” nie jest jeszcze dostatecznie rozpowszechniony ani jednoznacznie zdefiniowany i sklasyfikowany, a opracowania na ten temat mają przeważnie charakter informacyjny, lansujący i popularyzacyjny. Polska spółka Electric 
Vehicles Poland (EVP) określa mikromobilność jako światowy trend, który dopasowuje środki transportu do potrzeb miast i ich mieszkańców. Zdaniem EVP, mikromobilność to odpowiedź na potrzeby mieszkańców miast, a także wyjście naprzeciw potrzebom zrównoważonego transportu i reakcja na wprowadzoną w Polsce ustawę o elektromobilności (Mikromobilność, 2019). Spółka EVP przede wszystkim kojarzy mikromobilność z wdrażaniem do powszechnego użytkowania elektrycznych mikrosamochodów. Z kolei przedstawiciele Seata, charakteryzując mikromobilność, zwracają uwagę, że jest to zamiana samochodu w mieście na pojazd mniejszy, który łatwiej zaparkować, np. na hulajnogę, skuter, motocykl bądź mikrosamochód (Korniejew, 2019). Mikrosamochody dla miast oferują również takie firmy jak Renault (Twizy), Seat (Minimo) czy Toyota (i-Road) ${ }^{1}$. W motoryzacji mikrosamochody nie są nowością, gdyż były znane i produkowane od dawna, ale jako napęd wykorzystywano w nich niewielkie silniki spalinowe. Przykładowe wcześniejsze konstrukcje to polski Mikrus, japoński Kei-car czy włoski Fiat 500.

Znany serwis internetowy NewsAuto.pl przytacza szeroką definicję mikromobilności, którą to określa wszystkie rozwiązania komunikacyjne czy transportowe, umożliwiające pokonanie krótkich dystansów - z reguły pierwszego lub ostatniego odcinka zaplanowanej podróży. Według serwisu najlepiej do tego celu nadają się lekkie urządzenia zasilane prądem, takie jak rowery, hulajnogi, skutery czy małe samochody elektryczne. Dzięki niewielkim rozmiarom ułatwiają one poruszanie się po wąskich ulicach miast, a ich alternatywne zasilanie pozwala redukować ślad węglowy, czyli emisję dwutlenku węgla i innych gazów cieplarnianych (Chwist, 2019). Jednocześnie serwis NewsAuto.pl, powołując się na badania firmy McKinsey Center, z których wynika, że ok. 60\% podróży samochodami na całym świecie to przejazdy na dystansie mniejszym niż $8 \mathrm{~km}$, konkluduje, że znaczna część takich przejazdów mogłaby odbywać się z wykorzystaniem środków mikromobilności (Heineke, Kloss, Weig, 2019). W Stanach Zjednoczonych takie krótkodystansowe podróże nie przekraczają 4,8 km (Rowery i hulajnogi moga być..., 2019).

W opublikowanym w lipcu 2019 r. raporcie Współdzielona mobilność w Polsce zaliczano mikromobilność do sektora tzw. współdzielonej mobilności (ang. shared mobility), który to traktuje się jako nową, odrębną kategorię miejskiej mobilności obejmującą różne typy środków transportu (m.in. rowery, UTO, motocykle, skutery, samochody) przeznaczone do samodzielnego i indywidualnego korzystania. Najczęściej są one wypożyczane za pośrednictwem technologii mobilnych. Po zakończeniu podróży środek transportu staje się dostępny dla kolejnych użytkowników. Według przytoczonego raportu, mikromobilność stanowi rodzaj przemieszczania się przy użyciu pojazdów niewielkich rozmiarów i wagi, najczęściej jednoosobowych, np. rowerów, hulajnóg, motorowerów, ewentualnie trzykołowców czy innych UTO (Jędrzejewski, Domaszewicz, 2019). Należy przy tym również zauważyć, że środki transportu w mikromobilności nie zawsze muszą pochodzić z systemu wypożyczalni i być przedmiotem wspólnego użytkowania. Wiele z nich, np. rowery, jednokołowce, deskorolki czy hulajnogi, jest indywidualną własnością

\footnotetext{
${ }^{1}$ Pojazdy takie są zazwyczaj zasilane elektrycznie, nie emitują spalin i wykorzystują większość funkcji nowoczesnej e-łączności (e-connectivity) stosowanej w tradycyjnych samochodach. Koncepcja autonomicznych mikrosamochodów LUTZ Pathfinder, opracowana przez rząd brytyjski oraz brytyjską firmę RDM Group, czy EN-V stworzona przez firmy General Motors i Segway jest obecnie oceniana pod kątem przydatności dla współużytkowanych flot w miastach przyszłości (Sumatran, Fine, Gonsalvez, 2019). Warto zaznaczyć, że mikropojazdy mają masę własną poniżej $500 \mathrm{~kg}$ (Twizy - $450 \mathrm{~kg}$, i-Road - $350 \mathrm{~kg}$ ) i zajmują mało miejsca (np. na jednym miejscu parkingowym mogą zmieścić się cztery i-Roady).
} 
osób prywatnych i wyłącznie przez te osoby jest eksploatowanych. Zatem oprócz mikromobilności współdzielonej należy także wyróżnić mikromobilność indywidualną.

\section{Mikromobilność w przemieszczaniu się osób w miastach}

Każda podróż w mieście, jak pisze Szołtysek, składa się z łańcucha elementarnych przemieszczeń wykonywanych pieszo bądź z użyciem środków transportowych (Szołtysek, 2007). Przemieszczenia te tworzą łańcuch podróżowania. Typowa podróż w mieście z użyciem środków transportu zbiorowego rozpoczyna się od wędrówki pasażera do przystanku. Najczęściej jest to wędrówka piesza, niekiedy podróż taksówką lub rowerem, a ostatnio także - urządzeniem transportu osobistego. Następnie pasażer korzysta z tramwaju lub autobusu, aby po przesiadce zamienić go na szybszy środek transportu, którym może być metro, premetro lub kolej podmiejska. Zakończenie podróży zwykle przebiega podobnie jak i jej początek, choć odwrotnie.

Najczęściej spotykane sposoby podróżowania w europejskich miastach to korzystanie $\mathrm{z}$ transportu zbiorowego lub transportu indywidualnego - samochodów osobowych, taksówek, rowerów, skuterów, elektrycznych hulajnóg i motocykli, środków typu segway lub podróżowanie pieszo (rycina 1). Interesującymi rozwiązaniami są systemy łączące zalety podróżowania indywidualnego z zaletami podróżowania zbiorowego. Zaliczają się do nich m.in. takie systemy niekonwencjonalne, jak: PRT (ang. Personal Rapid Transit), CST (ang. Cybernetic Transport Systems) - systemy cybernetyczne, dwufunkcyjne DMV (ang. Dual Mode Vehicle), RUF Dual Mode Public Transport, a także MISTER (rycina 2). Systemy niekonwencjonalne są mało rozpowszechnione, niektóre wymagają specjalnej infrastruktury, dlatego pozostają w fazie koncepcji, prototypów lub pojedynczych wdrożeń, np. RUF DMP, MISTER, LOOP, deskolotka Lexusa i in. (Banach, 2015; Bejnar, 2016).

W Polsce do popularnych sposobów podróżowania należy transport indywidualny samochodami osobowymi, z którego najczęściej korzysta wyłącznie sam kierowca. Powolnie i z dużymi oporami wykorzystuje się zalety wspólnych przejazdów (carpoolingu), dzięki którym w samochodzie zapełnia się pozostałe miejsca. Do systemu transportowego polskich miast na trwałe wpisały się już rowery, trochę wolniej podążają za nimi skutery, elektryczne hulajnogi i inne UTO.

Rycina 1. Sposoby przemieszczania się osób w miastach

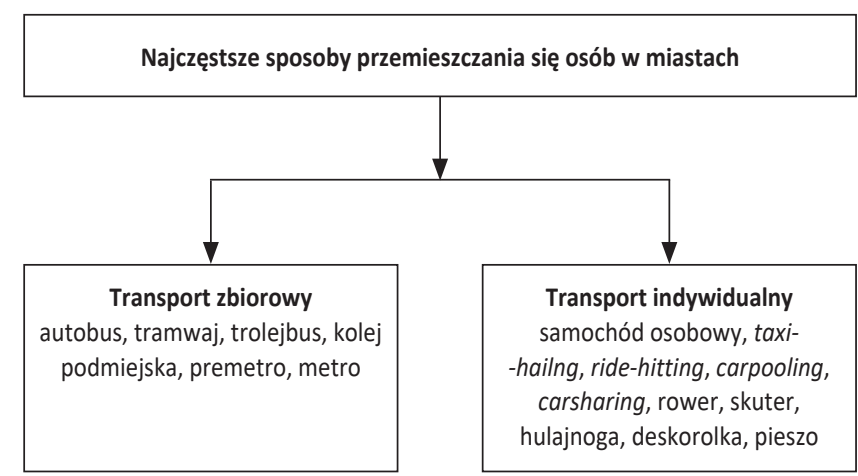

Źródło: opracowanie własne 
Rycina 2. Systemy transportu miejskiego

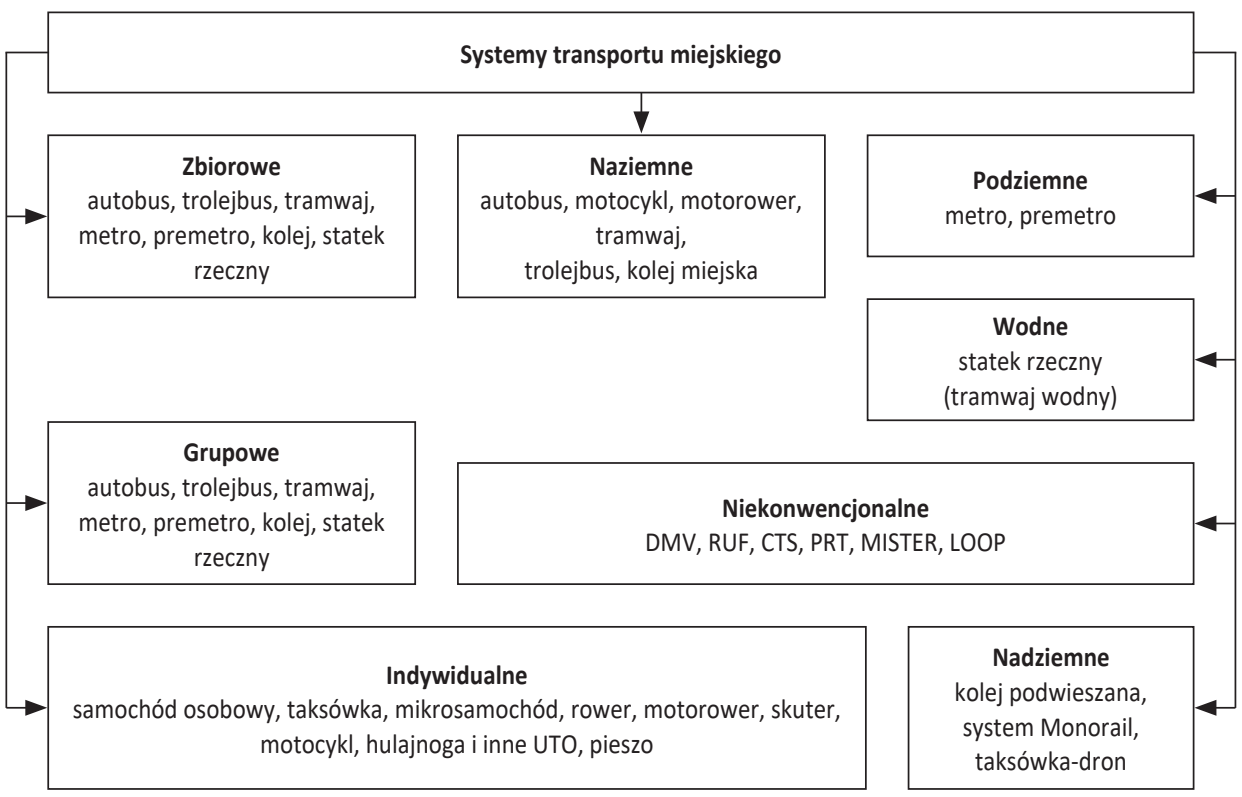

Źródło: Janczewski (2010: 25)

Transport indywidualny samochodami osobowymi preferują liczne grupy społeczne ze względu na jego niekwestionowane zalety, takie jak: możliwości przemieszczenia się od drzwi do drzwi, indywidualność podróżowania i bezpieczeństwo osobiste podróżnego. Niemniej jednak w niedalekiej przyszłości transport indywidualny samochodami osobowymi w miastach powinien stać się przeżytkiem. Dziś samochody tysiącami zalegają na parkingach blokowisk i powoli stają się przedmiotami bez większej wartości, a brak możliwości ich parkowania w centrach miast podważa sens ich użytkowania (Kauf, 2016a: 15).

Masowa motoryzacja związana $\mathrm{z}$ traktowaniem samochodu jako ogólnodostępnego dobra (niekiedy używanego wyłącznie dla zaspokojenia potrzeby poczucia wolności i niezależności) prowadzi do spowolnienia prędkości przemieszczania się w miastach, a w skrajnym przypadku do zupełnego zatrzymania ruchu na głównych arteriach. Nie bez znaczenia też pozostaje zajmowanie przez parkujące samochody deficytowej przestrzeni miejskiej. Wyzwaniem więc dla mobilności jest dążenie do redukcji ilości przepływów głównie realizowanych komunikacją indywidualną (Kauf, 2016). Zatem uzasadnionym jest rozpowszechnianie w miastach takich indywidualnych systemów, które umożliwiają wielokrotnie wykorzystanie tego samego samochodu osobowego lub urządzeń mikromobilności - mikrosamochodu (carsharing), roweru (bikesharing), skuteru (mopedsharing), hulajnogi (scootersharing) itp.

\section{Mikromobilność w transporcie towarów w miastach}

Transport towarów w miastach w przeważającej większości odbywa się z użyciem środków kołowych o małej, średniej i niekiedy - dużej ładowności. Rzadko wykorzystuje się infrastrukturę szynową, a jeszcze rzadziej - wodną. W fazie badań i zdobywania doświadczeń 
Rycina 3. Sposoby transportu ładunków w miastach

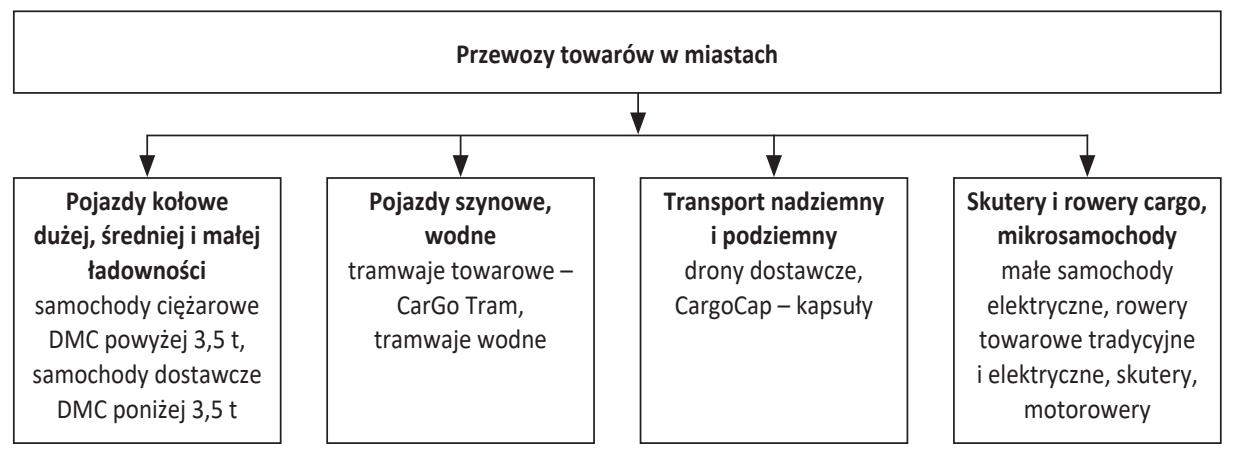

Źródło: opracowanie własne

pozostają transport naziemny i transport podziemny. Stosunkowo od niedawna rozpowszechniane są pojazdy wpisujące się w koncepcję mikromobilności (rycina 3).

Towary zwykle przewożone są do składów, magazynów, hurtowni, centrów logistycznych, zakładów przemysłowych, miejsc handlu i usług, dużych centrów handlowych, zakładów przemysłowych, miejsc prowadzenia budów, osób prywatnych i innych. Szacuje się, że ruch pojazdów ciężarowych w miastach stanowi 10-20\% całkowitego ruchu miejskiego (przejechanych kilometrów), a tylko 10\% całego transportu towarów w miastach wymaga dużego pojazdu, ponieważ przeciętny ładunek waży do $100 \mathrm{~kg}$ i ma $1 \mathrm{~m}^{3}$ objętości (Ziebura, Mazur, 2018).

W Warszawie, jak wynika z badań WBR 2015 (Warszawskie Badanie Ruchu), najwyższą ruchliwość wykazują pojazdy firm zaopatrujących lub obsługujących drobny handel i usługi. Pojazdy do 3,5 t mają znacznie wyższy wskaźnik ruchliwości w porównaniu z pojazdami powyżej 3,5 t wśród wszystkich rodzajów firm. Lżejsze pojazdy wykonują średnio dwie podróże więcej od pojazdów o wyższej dopuszczalnej masie całkowitej. W firmach zaopatrujących duże sieci handlowe pojazdy o niższym dmc wykonują średnio o trzy podróże więcej niż pojazdy cięższe. Największy ruch (32\%) pojazdów ciężarowych o dmc ponad 3,5 t związany jest z obsługą terenów budów. Największy ruch (49\%) pojazdów o dmc do 3,5 t związany jest z obsługą handlu i usług. Największy odsetek podróży rozpoczyna się między 7.00 a 8.00. Podróże pojazdami lżejszymi odbywane są głównie w godzinach przedpołudniowych, a pojazdami ciężkimi - równomiernie do godziny 16.00. Podróże pojazdami ciężkimi częściej trwają dłużej niż podróże pojazdami lżejszymi. Najwięcej podróży pojazdami lżejszymi trwa do 15 min. Najkrótsze są podróże odbywane pojazdami firm kurierskich. Również krótsze dystanse są pokonywane pojazdami firm zaopatrujących lub obsługujących małe obiekty handlowe (więcej w: Reksnis, 2018: 20-23).

Jak pisze S. Kauf, przepływy towarowe, choć są gwarantem funkcjonowania miast i regionów, to jednak ze względu na rozmiar, tempo poruszania się i częstotliwość postojów samochodów ciężarowych stwarzają ogromne utrudnienia w ruchu drogowym (Kauf, 2016b). W miastach pojazdy ciężarowe są parkowane na chodnikach, pasach ruchu, bezpośrednio na przejściach dla pieszych lub przed nimi, niektóre z nich (np. pojazdy obsługujące budowy) brudzą i niszczą nawierzchnię, blokują wjazdy i ciągi pieszych, niewspółmiernie przyczyniają się do powstawania zatorów, wzrostu hałasu i zanieczyszczenia środowiska oraz obniżenia poziomu bezpieczeństwa ruchu drogowego. Utrudnienia 
takie będą się jeszcze potęgowały, gdyż gwałtowny rozwój e-handlu przyczynia się do powstania nowych wzorców zachowań zakupowych konsumentów, a e-bussines dąży do permanentnego skracania czasu realizacji zamówień, a nawet dostaw w tym samym dniu. Tendencje te wymuszają rozbudowę sieci logistycznych i magazynowych na obszarach zurbanizowanych, gwarantujących niezakłócony przepływ towarów od pierwszej do ostatniej mili. W konsekwencji decentralizacja magazynowania spowoduje wzrost liczby przewozów, zmniejszenie wykorzystywania ładowności pojazdów, a tym samym zwiększenie natężenia ruchu oraz dalszą redukcję efektywności w transporcie ładunków (Kauf, 2016b). Wszystko to powinno prowadzić do szerszego zainteresowania towarowymi urządzeniami z obszaru mikromobilności, takimi jak skutery cargo, rowery cargo ${ }^{2}$, mikrosamochody czy nawet dostawcze drony.

\section{Mikromobilność w Polsce}

Firma Deloitte Polska w opracowaniu na temat mobilności współdzielonej (Deloitte Poland, 2019) stwierdza, że w polskich metropoliach jest bardzo duża liczba samochodów w stosunku do liczby ich mieszkańców. Inaczej jest w niektórych metropoliach zachodnich, gdzie dostępność alternatywnych środków transportu powoduje zmniejszenie w nich liczby samochodów osobowych. Według Deloitte ograniczeniu zależności od samochodów sprzyja rozwój nowych technologii, m.in.: rozwój GPS i płatności mobilnych w aplikacjach, zwiększenie pojemności zasobników energii elektrycznej czy udoskonalanie smartfonów.

Zdaniem Deloitte Polska, dynamiczne przemiany w obszarze mikromobilności mogą w ciągu kilku najbliższych lat doprowadzić do rewolucji w przemieszczaniu się w obszarach miejskich, gdyż stale rosnąca liczba mieszkańców (obecnie stanowią oni ok. 60\% populacji) oraz niska jakość powietrza w miastach wymuszają poszukiwanie nowych form transportu. Konieczne są jednak tutaj zmiany kulturowe, zmiany zachowań komunikacyjnych, szersza akceptacja społeczna nowych form transportu i wspierające działania samorządów (Mieszkańcy polskich miast pokochali mikromobilność, 2019).

Deloitte zauważa, że mieszkańcy polskich metropolii podążają za globalnym trendem mikromobilności i coraz częściej sięgają po rozwiązania komunikacyjne, które umożliwiają pokonywanie krótkich dystansów za pomocą lekkich pojazdów zasilanych prądem, takich jak rowery, hulajnogi, skutery czy małe samochody elektryczne. Firma zwraca także uwagę na zrównoważoną pozycję firm zajmujących się w Polsce wynajmem rowerów, na ich współpracę z samorządami, a także na rosnącą konkurencję ze strony usługodawców oferujących elektryczne hulajnogi lub skutery. Stabilna pozycja firm zajmujących się w Polsce wynajmem rowerów miejskich jest rezultatem przyjętego modelu biznesowego i jego finansowania. Przykładowo, przychód firmy Nextbike w 2017 r. wyniósł 44 mln zł, a rok później było to już $61 \mathrm{mln}$ zł. Zaledwie ułamek tego przychodu stanowiły opłaty od użytkowników. Trzy czwarte stanowiły przychody od miast, w których działają systemy rowerowe. Podobne zależności, jak przypuszcza Deloitte, występują zapewne u drugiego $\mathrm{z}$ dużych operatorów rowerowych - BikeU.

Firmy zajmujące się udostępnianiem hulajnóg i skuterów działają w odmiennym

${ }^{2}$ Według G. Amstronga 33\% wszystkich dostaw towarów w miastach europejskich można zrealizować przy pomocy rowerów towarowych (por. Amstrong, 2019: 9). 
modelu biznesowym, w którym nie istnieje finansowanie $\mathrm{z}$ budżetu miasta. W takich firmach przychody od klientów muszą pokryć koszty i zapewnić zyski na dalszy rozwój przedsięwzięcia, stąd stawki za użytkowanie hulajnóg, skuterów są o wiele wyższe niż za użytkowanie rowerów. Pomimo tego rozwiązania transportowe oferowane przez te firmy cieszą się dużym zainteresowaniem, a przyczynami tego stanu rzeczy mogą być: własny napęd takich urządzeń, elastyczność i swoboda użytkowania, brak stacji dokowania i jak dotychczas w przypadku hulajnóg elektrycznych - możliwość korzystania zarówno z infrastruktury rowerowej, jak i z infrastruktury dla pieszych (Dybalski, 2019).

W Polsce od października 2018 r. funkcjonują elektryczne hulajnogi amerykańskiej firmy Lime, dostępne we Wrocławiu, Poznaniu i Warszawie. Wiosną 2019 r. liczba tych hulajnóg w Warszawie wzrosła trzykrotnie. W sumie w sześciu największych miastach dostęp do ponad 6,5 tys. hulajnóg ${ }^{3}$ oferowało blisko 10 operatorów, m.in. firmy Lime, Bird, Hive (Deloitte Poland, 2019). Aby zwiększyć atrakcyjność systemu hulajnóg elektrycznych, posiadaczom karty miejskiej w Warszawie oraz Urbancard we Wrocławiu zaoferowano comiesięczne doładowanie w postaci 20 bezpłatnych minut na jazdę. Promocja miała na celu zachęcić kierowców do zrezygnowania z codziennego przemieszczania się samochodem osobowym po mieście na rzecz środków transportu publicznego oraz ekologicznych rozwiązań mobilnych (W poszukiwaniu hulajnóg..., 2019).

Za użytkowanie elektrycznych hulajnóg można płacić w formule PAYG (ang. pay as you go), a także w abonamencie. Tę drugą usługę testuje firma Bird, która zamierza ją na stałe wprowadzić w Poznaniu (Duszczyk, 2019a). Według danych firmy Lime z końca czerwca 2019 r., w Warszawie zanotowano ponad milion wypożyczeń hulajnóg elektrycznych i urządzeniami tymi pokonano w sumie dystans odpowiadający 49 okrążeniom Ziemi. Najdłuższy przejazd elektryczną hulajnogą wyniósł $26 \mathrm{~km}$. W opinii operatora hulajnóg, urządzenia te spotykają się z życzliwym przyjęciem mieszkańców Warszawy, gdyż uzupełniają jej system transportowy i stają się fragmentem rozwiązania problemów transportowych trapiących stolicę Polski - przede wszystkim korków i smogu. Z obserwacji firmy Lime wynika, że mieszkańcy Warszawy często wykorzystują hulajnogi, by dotrzeć do przystanków komunikacji miejskiej, jednocześnie jednak nie brakuje dłuższych przejazdów i sytuacji, w których hulajnogi bezpośrednio zastępują samochód (Postrzednik, 2019).

Zdaniem D. Martyniuk z zespołu doradztwa technologicznego Deloitte Polska, dynamiczny rozwój mikromobilności otwiera nowe możliwości dla biznesu. Szczególną aktywność zauważa się w branży motoryzacyjnej i energetycznej. Koncerny samochodowe stają się właścicielami sieci hulajnóg, a największe polskie firmy energetyczne, szukając dla siebie nowych kierunków rozwoju, inwestują w carsharing i popularyzowanie pojazdów elektrycznych. Pojawiają się również innowacyjne modele biznesowe, np. każda osoba może zainwestować w rozwój floty elektrycznych hulajnóg lub skuterów w ramach oferty tzw. społecznościowego użytkowania ${ }^{4}$ (Duszczyk, 2019b). Dynamicznie rośnie też rynek aplikacji integrujących wszystkie dostępne rozwiązania komunikacyjne,

\footnotetext{
${ }^{3}$ Dla porównania: w ciągu niespełna roku w Paryżu liczba elektrycznych hulajnóg przeznaczonych do wynajęcia doszła do 15 tys. (Paryż ma 15 tys. hulajnóg..., 2019).

${ }^{4}$ Deloitte przywołuje przykład operatora Blinkee, który pozwolił użytkownikom stać się operatorem. Wystarczy własny skuter lub hulajnogę dodać do systemu Blinkee, który jako operator zajmie się ich relokowaniem, a gdy będą wypożyczane, właściciel będzie zarabiał. Nie jest to nowy pomysł; np. w Holandii kilka lat temu aplikacja pozwalała na wypożyczanie własnego roweru i zarabianie na nim. Pomysł ten jednak nie rozpowszechnił się wystarczająco (Dybalski, 2019).
} 
pozwalających lokalizować najbliższe środki komunikacji i planować intermodalną trasę przejazdu (Mieszkańcy polskich miast pokochali mikromobilność, 2019).

Najnowsze dane (lipiec 2019) na temat sektora shared moblity zostały przedstawione w raporcie Na progu przełomu. Współdzielona mobilność w Polsce - lipiec 2019. Jego autorzy reprezentują branżowe stowarzyszenie Mobilne Miasto oraz portal SmartRide.pl poświęcony tematyce mikromobilności. Raport charakteryzuje rynek współużytkowania rowerów, hulajnóg, skuterów i samochodów w Polsce. Opisuje jego stan obecny, zasady funkcjonowania branży, rozwój i prognozy na następne lata, wyzwania oraz nowe trendy i zjawiska we współdzielonej mobilności. Zdaniem autorów raportu, współdzielona mobilność będzie oferowana w coraz większej liczbie polskich miast, a najszybszy przyrost liczebności flot współdzielonych przewidywany jest w kategoriach lekkich jednośladów elektrycznych - hulajnóg i skuterów. Według przedstawionych w raporcie prognoz, w latach 2019-2025 liczba tych pojazdów wypożyczanych na minuty zwiększy się w Polsce o 505\%. Uwagę zwraca również fakt, że co czwarty współdzielony środek lokomocji w Polsce napędzany jest elektrycznie. Dodatkowo, jeśli uwzględnić 1,8 tys. rowerów ze wspomaganiem elektrycznym, udział ten sięga aż 30\%. Autorzy raportu domniemywają, że współdzielona mobilność umożliwi szybką popularyzację środków transportu należących do mikromobilności, które są przydatne jako środki lokomocji na krótkie i średnie dystanse, dają dużą swobodę przemieszczania się w mieście, a przy tym rozwiązują, tzw. problem pierwszej i ostatniej mili. Istotny jest również wpływ współdzielonej mobilności na zwyczaje komunikacyjne mieszkańców miast. Świadomość istnienia łatwo dostępnej i mocno zróżnicowanej oferty przejazdów może sprzyjać wykorzystywaniu tzw. transportu multimodalnego, czyli łączenia w podróży różnych środków lokomocji i zwiększania tym samym efektywności komunikacji (szerzej w: Jędrzejewski, Domaszewicz, 2019).

W czerwcu 2019 r. Ubezpieczeniowy Fundusz Gwarancyjny (UFG) przeprowadził badanie omnibus CAPI dotyczące użytkowników hulajnóg elektrycznych w Polsce. Badanie prowadzono metodą wywiadów bezpośrednich, w domach respondentów, na podstawie reprezentatywnej losowej próby Polaków w wieku 15+. Całkowita liczba zrealizowanych wywiadów wyniosła 1005.

Według badań UFG, prawie 10\% Polaków korzysta z elektrycznych hulajnóg. Większość z nich czyni to rzadziej niż raz w tygodniu lub okazjonalnie. Największa grupa, która deklaruje korzystanie z tych urządzeń, to osoby w wieku nieprzekraczającym 20 lat (tzw. nastolatki) - stanowią one blisko $30 \%$ osób badanych za pomocą wywiadów. Osoby te są niechętne wprowadzeniu restrykcji w ruchu dla takich środków transportu i choć, jak twierdzi portal UFG, blisko 75\% ogółu badanych Polaków uważa, że kierujących elektrycznymi hulajnogami powinny obowiązywać: ograniczenia prędkości (rycina 4) oraz zakaz jazdy pod wpływem alkoholu, to jednak sami użytkownicy hulajnóg w aż $42 \%$ są przeciwni wprowadzeniu dla nich ograniczeń prędkości, a z kolei $44 \% \mathrm{z}$ nich jest przeciwnych wprowadzaniu zakazu jazdy pod wpływem alkoholu (rycina 5). W tej grupie badanych tylko połowa opowiadała się za takimi ograniczeniami, reszta nie miała zdania.

Korzystający z elektrycznych hulajnóg niechętni są też wprowadzaniu dla nich udokumentowanej znajomości przepisów ruchu drogowego - za takimi regulacjami było tylko $54 \%$ korzystających z tych pojazdów, zaś przeciwnych - 42\%. W przypadku ogółu respondentów: $62 \%$ chciało wprowadzenia udokumentowanej znajomości zasad ruchu drogowego dla kierujących elektrycznymi hulajnogami, 22\% było temu przeciwnych, reszta nie miała zdania (rycina 6). 
Rycina 4. Ograniczenia prędkości e-hulajnóg w opinii badanych

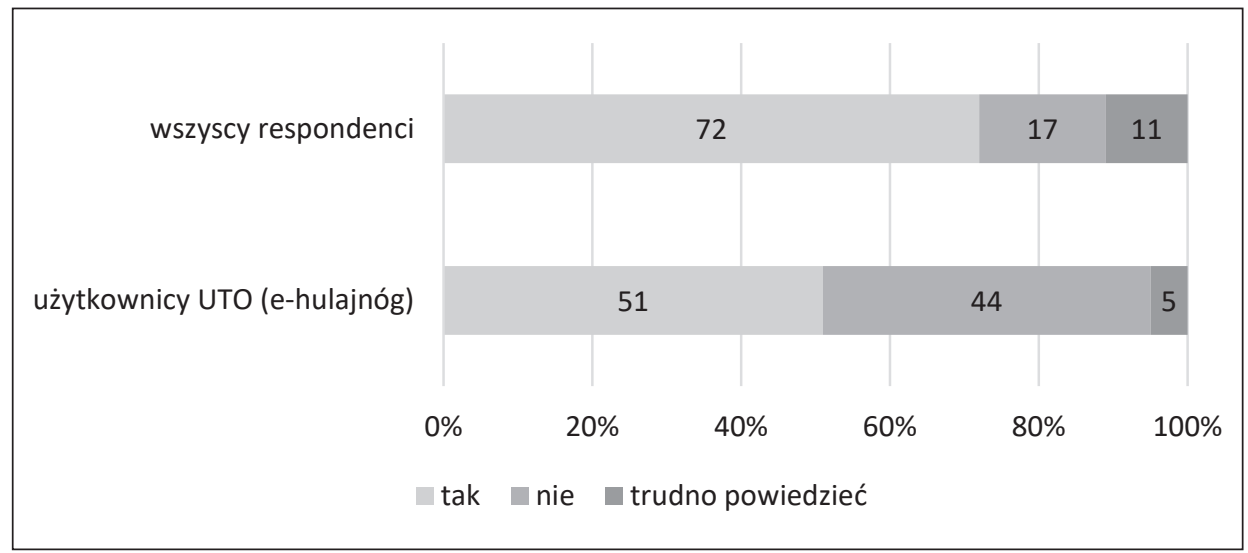

Źródło: opracowanie własne na podstawie wyników badań UFG

Rycina 5. Opinia badanych osób o zakazie jazdy e-hulajnogami pod wpływem alkoholu

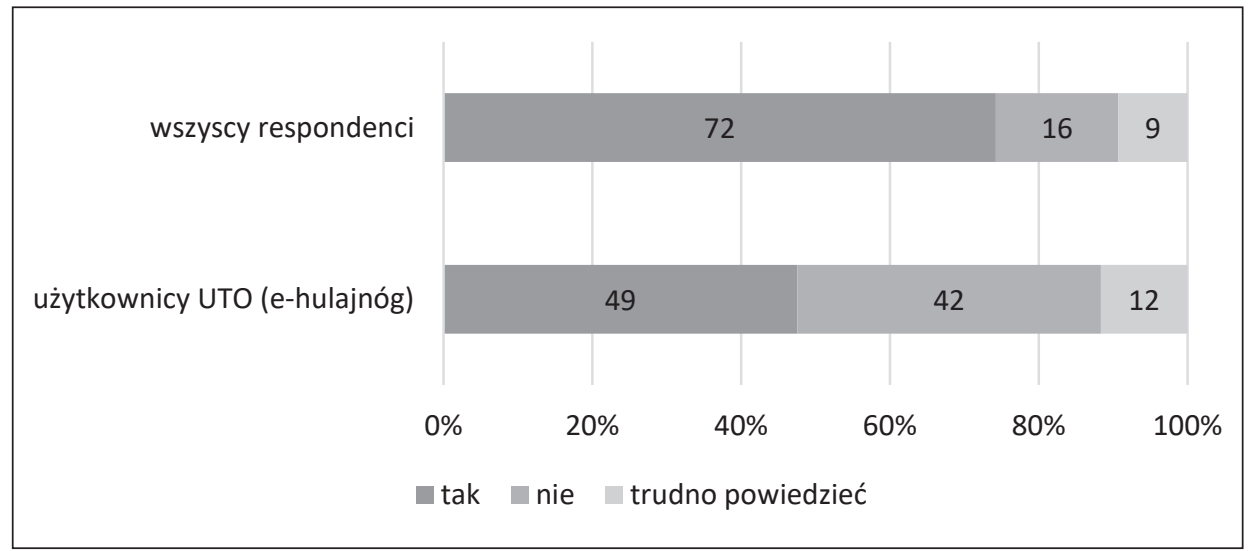

Źródło: opracowanie własne na podstawie wyników badań UFG

Rycina 6. Opinia badanych osób o konieczności posiadania udokumentowanej znajomości przepisów ruchu drogowego

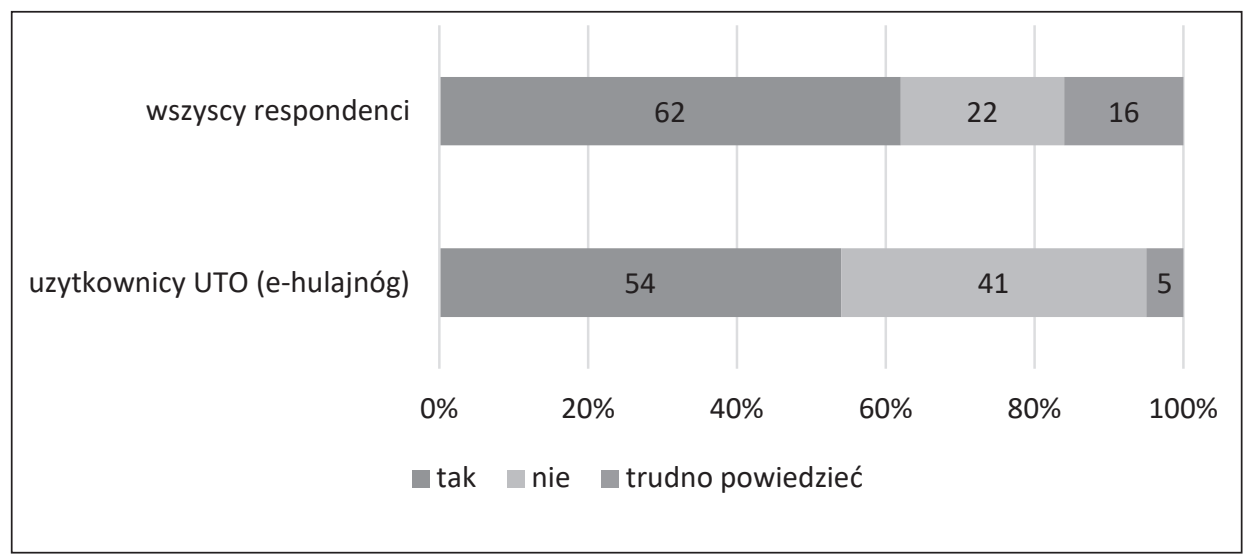

Źródło: opracowanie własne na podstawie wyników badań UFG 
Z kolei jeżeli chodzi o ubezpieczenie od odpowiedzialności cywilnej (OC), to największa grupa ogółu respondentów jak i samych użytkowników e-hulajnóg - 45\% - opowiedziała się za wprowadzeniem dla kierujących elektrycznymi hulajnogami obowiązku posiadania takiej polisy. Natomiast o ile $25 \%$ ogółu badanych uważało, że ubezpieczenie to powinno być dobrowolne, o tyle w grupie użytkowników tych urządzeń było ich $36 \%$, reszta - nie miała zdania. W opinii UFG może to świadczyć o tym, że pewność otrzymania odszkodowania z polisy OC jest już zakorzeniona w świadomości Polaków, ale nie wiąże się z refleksją, że najpierw trzeba zapłacić składkę, żeby było z czego wypłacać odszkodowanie, a przy braku obowiązku rejestracji elektrycznych hulajnóg, a tym samym ich ewidencji - zbieranie składek i kontrola spełnienia obowiązku posiadania ubezpieczenia OC są co najmniej wątpliwe.

Aktualnie (sierpień 2019) użytkownicy elektrycznych hulajnóg traktowani są jak piesi i zobowiązani do korzystania z chodników. Z badań UFG wynika, że większość Polaków nie chce, by hulajnogi poruszały się po chodnikach (51\% badanych). Respondenci najchętniej widzieliby te nowe środki transportu na ścieżkach rowerowych (64\% odpowiedzi), a w drugiej kolejności - na jezdniach na zasadach obowiązujących pieszych (41\%). Z kolei sami użytkownicy elektrycznych hulajnóg są znacznie mniej przychylni ścieżkom rowerowym - za nimi opowiada się tylko 50\%; częściej za to wskazują oni jezdnię - jako ciąg komunikacyjny do poruszania się urządzeniami transportu osobistego, przy czym poruszanie się po niej na hulajnogach miałoby się odbywać na zasadach obowiązujących pieszych - 47\% wskazań w tej grupie badanych (Użytkownicy hulajnóg przeciwni..., 2019).

W Polsce, podobnie jak i w wielu innych krajach, mikromobilność, a szczególnie utożsamiane $\mathrm{z}$ nią używanie elektrycznych hulajnóg stwarza szereg problemów, m.in. z dostępnością do infrastruktury, kolizjami i bezpieczeństwem użytkowników, odpowiedzialnością cywilną (Eksperci o OC..., 2019), niedbałym parkowaniem, niewłaściwym użytkowaniem, a także niewłaściwymi zachowaniami osób uczestniczących w tym systemie. Zauważa się w tym zakresie niedostatek dostępnych badań i publikacji. Brakuje badań, które pokazałyby poziom zagrożenia, np. powodowanego przez użytkowników elektrycznych hulajnóg w porównaniu $\mathrm{z}$ użytkownikami innych środków transportu oraz w jaki sposób prędkość czy użycie lub brak kasku ochraniającego głowę wpływają na poziom bezpieczeństwa użytkowników hulajnóg. Nierozwiązanym problemem jest kwestia środków transportu niewymagających stacji dokujących, które są pozostawiane przez ich użytkowników w zupełnie przypadkowych miejscach (Mieszkańcy polskich miast..., 2019). Ponadto brakuje uregulowań prawnych w zakresie definiowania niektórych środków transportu mikromobilności, potrzeby ich homologacji i posiadania numeru rejestracyjnego, obowiązkowego ubezpieczenia, dostępu do infrastruktury przeznaczonej dla osób niezmotoryzowanych/zmotoryzowanych lub zachowań użytkowników tych urządzeń względem innych uczestników ruchu.

\section{Mikromobilność w świetle wstępnych badań własnych}

W czerwcu 2019 r. w ramach badań własnych autor niniejszego artykułu przeprowadził wśród studentów studiów zaocznych i stacjonarnych kierunkutTransport i kierunku zarządzanie w AHE w Łodzi wstępne rozpoznanie dotyczące wykorzystywania mikromobilności i opinii na jej temat. Do tego celu użył kwestionariusza ankietowego ${ }^{5}$ W bada-

${ }^{5}$ https://docs.google.com/forms/d/1TWaskXIpXNAlPF28YuemN_-hLqUDFS3fRXSg3-TwYhY/edit\#responses: 2019, 17 lipiec. 
niu udział wzięło 67 osób (43 mężczyzn, 24 kobiety), z których 63 to osoby korzystające $\mathrm{z}$ środków transportu w ramach mikromobilności. W badaniu dominowały dwie grupy wiekowe: 20-30 lat - 29 osób i 30-40 lat - 22 osoby. Najmniej liczną grupę, bo po 3 osoby, stanowili studenci poniżej 20 lat i w przedziale 60-70 lat. Ankietowane osoby mieszkały na wsi (14 osób), w miastach do 50 tys. mieszkańców (20 osób) i do 100 tys. mieszkańców (9 osób). Liczna grupa badanych mieszkała w miastach powyżej 100 tys. - 15 osób i w metropoliach - 9 osób. Najwięcej badanych osób (59) mieszkało w Polsce, zaś 8 ankietowanych osób mieszkało za granicą (Holandia, Niemcy, UK, Irlandia).

Autor zadał studentom następujące pytania: Czy korzystają z mikromobilnych środków transportu?, Czy są to ich prywatne urządzenia, czy służbowe lub wypożyczone i jakiego są one rodzaju?, Jak często i do jakich celów wykorzystują te środki?, Czy w ich opinii środki transportu wykorzystywane w mikromobilności ograniczają kongestię w miastach i wspomagają rozwiązać problem pierwszej/ostatniej mili? Czy elektryczne hulajnogi itp. środki transportu powinny mieć dostęp do infrastruktury rowerowej i czy stanowią one zagrożenie dla osób pieszych? Jeżeli tak, to jak można temu przeciwdziałać?

$\mathrm{Z}$ odpowiedzi udzielonych przez studentów wynikało, że niemal wszystkie ankietowane osoby (63, czyli $94 \%$ badanych) korzystają z mikromoblinych środków transportu. Najwięcej osób wykorzystuje je kilka razy w tygodniu (24 osoby - 38\%), nieco mniej osób - raz w tygodniu (10 osób - 16\%). Codziennie korzysta z nich 7 osób (11\%), również 7 osób (11\%) deklaruje korzystanie z takich urządzeń raz w miesiącu i 7 (11\%) kilka razy w miesiącu. Pozostałe 6 osób (10\%) ze środków transportu mikromobilności korzysta rzadziej niż raz miesiącu, a jedna osoba częstotliwość ich wykorzystania uzależnia od pory roku, tj. latem korzysta kilka razy w tygodniu, zimą - wcale. Najczęściej są to prywatne urządzenia osób ankietowanych, co deklarowało 58 osób (92\%), w mniejszym stopniu wypożyczone (11 osób - 18\%), a najrzadziej - służbowe (5 osób - 8\%). Najbardziej popularnym środkiem jest tradycyjny rower, z którego korzysta 56 badanych osób (89\%). Z łyżworolek korzysta 18 osób (29\%), z hulajnogi tradycyjnej - 5 osób (8\%), podobnie 5 osób (8\%) korzysta z hulajnogi elektrycznej, 3 osoby (5\%) korzystają z wrotek i 3 (5\%) z tradycyjnej deskorolki. Tylko 2 osoby (3\%) korzystają z roweru elektrycznego, elektrycznej deskorolki, mikrosamochodu z napędem spalinowym i wózka napędzanego siłą własnych mięśni. Z urządzenia typu segway i mikrosamochodu z napędem elektrycznym żadna z badanych osób nie korzysta. Rodzaje wykorzystywanych środków transportu mikromobilności według liczby wskazań zostały przedstawione na rycinie 7.

Ankietowane osoby najczęściej wykorzystywały mikromobilne środki transportu dla celów rekreacyjnych i sportowych (56 osób, czyli 89\%), rzadziej - w celu dojazdu do pracy i do szkoły (23 osoby - 37\%), jeszcze rzadziej - w celu dojazdu do najbliższego przystanku komunikacji zbiorowej (6 osób - 10\%) i powrotu po zakończeniu podróży (4 - 6\%), najrzadziej - w celu dowożenia przesyłek do klientów $(2-3 \%)$ i do przemieszczania się po korytarzach biur, pawilonach itp. (1 osoba $-2 \%)$. Obrazuje to rycina 8.

Zdaniem większości (59 osób, tj. 88\%) ankietowanych osób mikromobilność pomaga ograniczać zatłoczenie w miastach. Tylko 4 osoby (6\%) sądziły przeciwnie, zaś 4 osoby nie miały na ten temat wyrobionego zdania. Natomiast 23 osoby (34\%) uważały, że mikromobilne urządzenia ułatwiają rozwiązać problem tzw. pierwszej i ostatniej mili osób lub ładunków. Więcej, bo 35 osób (52\%) sądziło, że urządzenia te tylko częściowo ułatwiają rozwiązać ten problem, 7 osób (10\%) nie miało na ten temat wyrobionego zdania, zaś 2 osoby (3\%) stwierdziły, że jest odwrotnie, czyli środki transportu mikromobilności nie pomagają rozwiązać problemu tzw. pierwszej i ostatniej mili. 
Rycina 7. Rodzaje wykorzystywanych środków transportu mikromobilności według liczby wskazań

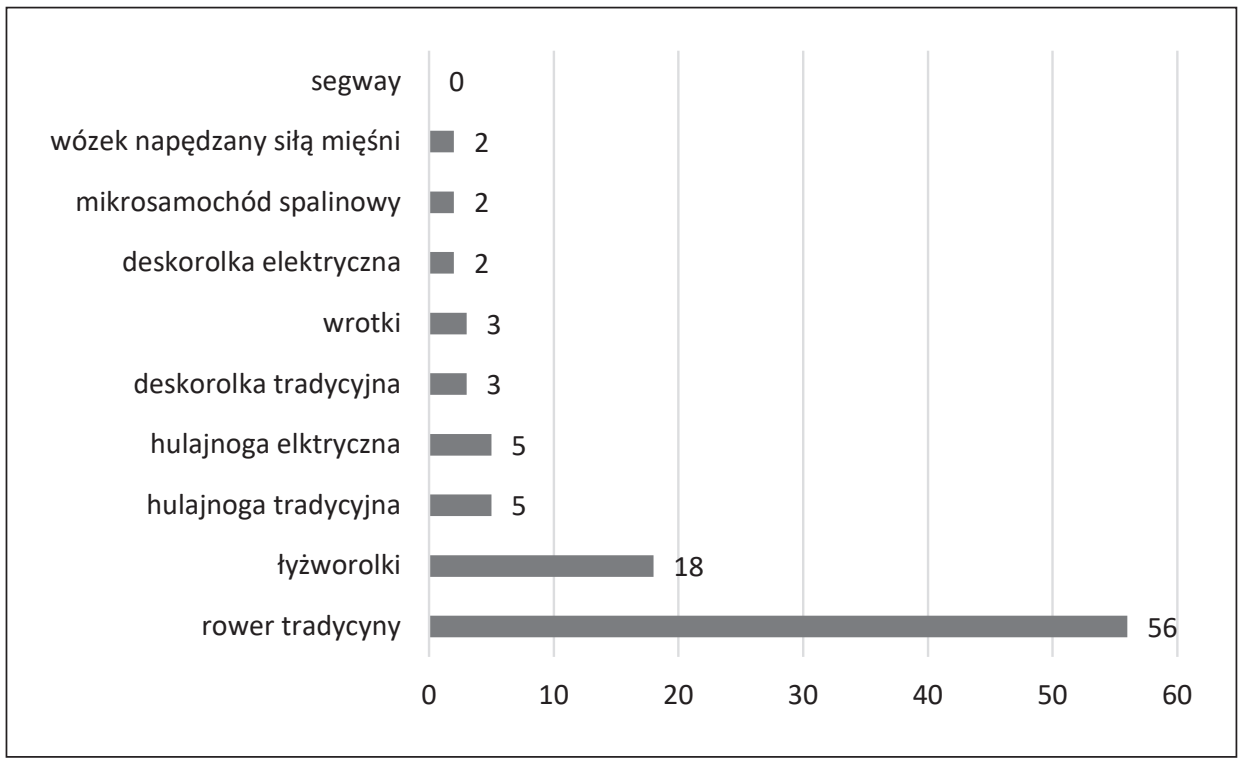

Źródło: opracowanie własne autora

Rycina 8. Cel korzystania z środków transportu mikromobilności według liczby wskazań

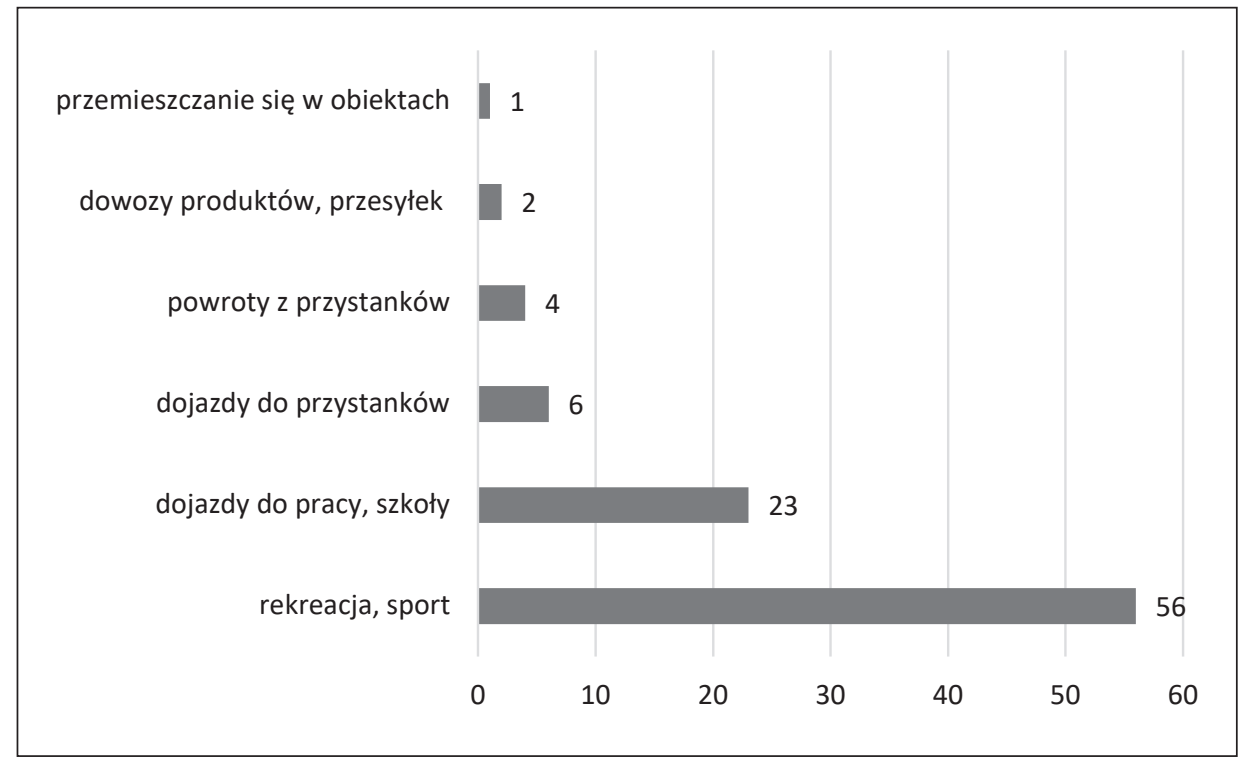

Źródło: opracowanie własne autora

Badanie wykazało również, że większość badanych osób (44) (68\%) akceptuje dla takich urządzeń, jak: elektryczne hulajnogi, segway, rolki itp. dostęp do infrastruktury rowerowej, jednak 14 osób (22\%) taką dostępność akceptuje z pewnymi ograniczeniami, 4 osoby (6\%) nie mają na ten temat wyrobionego zdania, zaś 3 osoby (5\%) są temu przeciwne. 
Podobne były opinie dotyczące bezpieczeństwa osób poruszających się po chodnikach, tutaj 45 osób (67\%) uważało, że elektryczne hulajnogi, segway, rolki w pewnym stopniu stanowią zagrożenie dla osób poruszających się po chodnikach, 16 osób (24\%) twierdziło, że zdecydowanie tak zaś zupełnie przeciwnego zdanie posiadało 6 osób (9\%). W większości ankietowani (34 osoby) (52\%) uważali, że elektryczne hulajnogi, segwaye, rolki itp. powinny mieć częściowy dostęp do infrastruktury dla pieszych, z pewnymi wyłączeniami i ograniczeniami, 14 osób (21\%) opowiedziało się za całkowitym zakazem dostępu do infrastruktury dla pieszych, zaś 18 osób (27\%) proponowało inne sposoby, np. budowę specjalnych ścieżek, odpowiednie uregulowania lub tylko zachowanie szczególnej ostrożności przez pieszych i użytkowników mikromobilnych urządzeń.

\section{Podsumowanie}

W miastach wielu mieszkańców korzysta z prywatnych samochodów osobowych. Bezpośrednią przyczyną takiego stanu jest konieczność przebycia, najczęściej pieszo, długiego dystansu do najbliższego przystanku komunikacji zbiorowej, a później do celu podróży. Komunikacja publiczna, z natury nastawiona na masowość, wykorzystuje duże pojazdy, które nie są w stanie dotrzeć do każdego miejsca w mieście. System potrzebuje zatem uzupełnienia o dodatkowe formy przemieszczania się pasażerów. Dotyczy to również drobnych ładunków i przesyłek, które w ostatnim kilometrze przewozu są dostarczane do finalnych odbiorców przez nie w pełni wykorzystane samochody dostawcze.

Mikromobilność nie ma jednoznacznej definicji i może odnosić się zarówno do rowerów, motorowerów, mikrosamochodów, hulajnóg, deskorolek, jak i do autonomicznej mobilności. Środki transportu wykorzystywane w jej ramach stale przenikają do systemów transportowych, stając się cechą charakterystyczną dróg, ścieżek i chodników szczególnie w dużych miastach, miejscowościach wypoczynkowych, miasteczkach uniwersyteckich, biurach, urzędach, halach targowych, wystawowych itp.

Mikromobilność to po elektromobilności kolejny nurt w logistyce oraz transporcie i tym samym - wyzwanie dla społeczeństw, organów publicznych zajmujących się transportem w miastach, a także producentów środków transportu. W Polsce nie prowadzi się wielu badań nad mikromobilnością, choć przewozy z użyciem jej środków transportowych stają się coraz bardziej popularne i widoczne.

Mikromobilność może być jednym ze sposobów na rozwiązanie problemu tzw. pierwszego i ostatniego kilometra zarówno w przemieszczaniu się osób, jak i w transporcie niewielkich ładunków. W postępie mikromobilności bardzo istotne staje się właściwe zarządzanie nią, w tym rozbudowa tzw. niezmotoryzowanej infrastruktury, poszerzenie dostępności do niej, uzupełnianie, modyfikowanie i szybkie przyjmowanie stosownych uregulowań prawnych, opracowanie standardów bezpieczeństwa, homologowanie wybranych urządzeń, kontrolowanie i nadzór nad tymi urządzeniami w ruchu i wiele innych. Mikromobilności towarzyszy wiele barier, czego przykładem stały się bariery związane $\mathrm{z}$ intensywnym ostatnio rozpowszechnianiem w miastach elektrycznych hulajnóg i innych podobnych urządzeń zaliczanych do środków transportowych mikromobilności. Zatem konieczne są stałe badania w tym zakresie i dostosowywanie obowiązującego prawa drogowego do nowych form transportu.

Wstępne rozpoznanie autora przeprowadzone wśród studentów wskazuje na duże zainteresowanie formami mikromobilności. Wysoki odsetek korzystających 
z mikromobilnych rozwiązań dotyczy wyłącznie osób badanych i nie może być podstawą do uogólnień. Jak wynika z rozpoznania, dominującym środkiem transportowym jest rower, co jest rzeczą oczywistą ze względu na jego duże rozpowszechnienie i długą tradycję wykorzystywania. Niemniej jednak uczestnicy badania korzystają też z innych mikromobilnych środków transportu, które wykorzystują w dojazdach do pracy, szkoły lub do najbliższych przystanków komunikacji zbiorowej. Prawie wszyscy uczestnicy badania są zgodni, że mikromobilność może mieć wpływ na rozwiązywanie niektórych problemów komunikacyjnych w miastach, zwłaszcza problemu pierwszego i ostatniego kilometra, a także nadmiernego zatłoczenia. Większość badanych osób opowiada się za dostępem do elektrycznych hulajnóg w infrastrukturze rowerowej. Przy czym zdaniem tych osób możliwy też powinien być dostęp elektrycznych hulajnóg do infrastruktury dla pieszych, lecz z pewnymi ograniczeniami, np. prędkości. Pewne zaniepokojenie wywołują tutaj wyniki badań UFG, w których to użytkownicy elektrycznych hulajnóg są niechętni wprowadzeniu restrykcji w ruchu, a także wprowadzaniu dla nich konieczności udokumentowania znajomości przepisów ruchu drogowego.

Literatura

Refernces

Amstrong, G. (2019, 28 lipca). City Changer Cargo Bike. Pozyskano z: http://eclf.bike/onewebmedia/ CCCB\%20ECLF\%20Dublin\%20Gary\%20Armstrong.pdf

Banach, M. (2015, 21 lipca). Lexus Hoverboard, czyli prawdziwa deskolotka. Pozyskano z: https://www. smartage.pl/lexus-hoverboard-czyli-prawdziwa-deskolotka/

Bejnar, K. (2016, 21 lipca). 14 innowacji, które wkrótce rozładują korki w miastach. Pozyskano z: https:// www.trans.eu/pl/blog/branza-tsl/14-sposobow-na-korki

Bruce, O. (2018, 11 maja). Episode 2: What is micromobility, how do we define it, and why is it disruptive? Pozyskano z: https://medium.com/micromobility/episode-2-what-is-micromobility-how-do-wedefine-it-and-why-is-it-disruptive-4653ef260492

Budzik, T. (2019, 4 lipca). Los silników spalinowych jest przesadzony. Zostało im najwyżej 30 lat. Pozyskano z: https://e.autokult.pl/34166,los-silnikow-spalinowych-jest-przesadzony-zostalo-im -najwyzej-30-lat?src01=c801b

Chwist, I. (2019; 10 maja). Mikromobilność. Pięć rzeczy, które warto wiedzieć. Pozyskano z: http://www. newsauto.pl/mikro-mobilnosc-piec-rzeczy-ktore-warto-wiedziec/

Dediu, H. (2019, 2 maja). The Micromobility Definition. Pozyskano z: https://micromobility.io/ blog/2019/2/23/the-micromobility-definition.

Duszczyk, M. (2019a, 31 lipca). Hulajnogi i auta będa jak Netflix. W abonamencie. Pozyskano z: https:// moto.rp.pl/tu-i-teraz/29776-hulajnogi-i-auta-beda-jak-netflix-w-abonamencie

Duszczyk, M. (2019b, 31 lipca). Jak zostać królem hulajnóg. Pozyskano z: https://moto.rp.pl/dwa-kolka/26297-jak-zostac-krolem-hulajnog

Dybalski, J. (2019, 30 lipca). Czy na mikromobilności można zarobić bez wspótpracy z miastem?. Pozyskano z: https://www.transport-publiczny.pl/wiadomosci/czy-na-mikromobilnosci-mozna-zarobic-bez-wspolpracy-z-miastem-61712.html

Eksperci o OC dla hulajnóg. (2019, 11 lipca). Dziennik Ubezpieczeniowy. Pozyskano z: https://dziennikubezpieczeniowy.pl/2019/07/10/Eksperci_o_OC_dla_e-hulajnog/artykul/120692.

Heineke, K., Kloss, B., Weig, F. (2019, 10 maja). Micromobility's - 15,000-mile checkup. Pozyskano z: https://www.mckinsey.com/industries/automotive-and-assembly/our-insights/micromobilitys-15000-mile-checkup

Historia roweru - 200 lat ewolucji. (2019; 17 czerwca). Pozyskano z: https://www.bikester.pl/info/historia-roweru 
Janczewski, J. (2010). Współużytkowanie rowerów i samochodów w komunikacji miejskiej - niewykorzystane możliwości. Zarządzanie Innowacyjne w Gospodarce i Biznesie, 2(11), 24-33.

Jędrzejewski, A., Domaszewicz, Z. (2019, 30 lipca). Na progu przełomu: Współdzielona mobilność w Polsce - lipiec 2019. Pozyskano z: http://mobilne-miasto.org/wp-content/uploads/2019/07/ Raport_Shared_Mobility_2019_PL_maly.pdf

Kauf, S. (2016a). Przyszłość mobilności indywidualnej - kreowanie sieci mobilności. Logistyka, 3, 15-19.

Kauf, S. (2016b). Współczesne wyzwania dla logistyki miasta- kształtowanie nowych struktur przestrzennych w dostawach towarów. Zeszyty Naukowe Politechniki Częstochowskiej. Zarządzanie, 24(1), 128-139.

Korniejew, T. (2019, 10 maja). Jaka jest najbliższa przyszłość motoryzacji? Seat stanie się platforma dostarczająca ustugi mobilności. O co w tym chodzi?. Pozyskano z: http://moto.pl/ MotoPL/7,88389,24574375,jaka-jest-najblizsza-przyszlosc-motoryzacji-seat-stanie-sie.html

Micromobility in Cities. A history and policy overview. (2019, 2 maja). Pozyskano z: https://www.nlc.org/ sites/default/files/2019-04/CSAR_MicromobilityReport_FINAL.pdf

Mieszkańcy polskich miast pokochali mikromobilność. (2019, 2 lipiec). Pozyskano z: https://www2.deloitte.com/pl/pl/pages/press-releases/articles/mieszkancy-polskich-miast-pokochali-mikromobilnosc.html

Mikromobilność. (2019, 2 maja). Pozyskano z: https://evpoland.pl/Models/Micromobility

Mobility 2040 Staying Ahead Of Disrubtion. (2016; 2019, 27 sierpnia). Pozyskano z: https://www.oliverwyman.de/content/dam/oliver-wyman/global/en/2016/nov/Mobility2040ReportWeb.pdf

Nowicka, K. (2017). Rozwój świata wirtualnego i jego wpływ na e-mobilność. W: J. Gajewski, W. Paprocki, J. Pieriegud (red.), E-mobliność: wizje i scenariusze rozwoju, Publikacja Europejskiego Kongresu Finansowego, Centrum Myśli Strategicznych, Sopot.

Paryż ma 15 tys. hulajnóg do wynajęcia. (2019, 27 lipca). Pozyskano z: http://infobike.pl/paryz-ma-15-tys-hulajnog-do-wynajecia_more_116130.html

Philpott, M. The Happy Walker Consortium. (2013; 2019, 8 maja). D1.1 Literature review of the older adults' mobility needs and services for mobility. Edition v 1.1. Pozyskano z: http://deliverables. aal-europe.eu/call-4/happy-walker/hw_d1-1_v1.1/at_download/file

Postrzednik, J. (2019, 5 lipca). Hulajnogi elektryczne. Warszawiacy wykonali już milion przejazdów i pokonali dystans odpowiadający 49 okrążeniom Ziemi. Pozyskano z: http://warszawa.naszemiasto.pl/artykul/hulajnogi-elektryczne-warszawiacy-wykonali-juz-milion,5182213,artgal,t,id,tm. html

Reksnis, M. (2018; 2019, 16 czerwca). Rozwiazania dotyczące transportu ładunków w Warszawie. Konferencja „Miasto i Transport 2019”. Warszawa. Pozyskano z: http://www.miastoitransport. il.pw.edu.pl/mit_materialy.html

Rowery i hulajnogi moga być konkurencja dla samochodów w USA. (2019, 3 lipca). Pozyskano z: http:// infobike.pl/rowery-i-hulajnogi-moga-byc-konkurencja-dla-samochodow-w-usa_more_106614. html

Deloitte Poland. (2019, 2 maja). Shared mobility in Poland - Overview. Pozyskano z: https://www.teraz-srodowisko.pl/media/pdf/aktualnosci/6982-mobility-in-poland-2019.pdf

Segwahy HT. ( 2014; 2019, 2 maja). Pozyskano z: https://pl.wikipedia.org/wiki/Segway_HT.

Shin, G.W., Lee, K.J., Park, D. (2018, 1 maja). Personal Mobility Device and User Experience: A State-of-theart Literature Review. Pozyskano z: https://journals.sagepub.com/doi/10.1177/1541931218621305

Scheurenbrand, J., Engel, C., Peters, F., Kühl, N. (2015, 24 czerwca). Holistically Defining E-Mobility: A Modern Approach to Systematic Literature Reviews. Pozyskano z: https://www.researchgate. net/publication/292142231_Holistically_Defining_E-Mobility_A_Modern_Approach_to_ Systematic_Literature_Reviews

Sumatran, V., Fine, Ch., Gonsalvez, D. (2019, 10 maja). Transport miejski dostępny „na żadanie”. Pozyskano z: https://mitsmr.pl/w-strone-mobilnosci-spersonalizowana-przyszlosc-transportu-miejskiego-dostepnego-na-zadanie/ 
Szołtysek, J. (2007). Podstawy logistyki miejskiej. Katowice: Akademia Ekonomiczna w Katowicach.

Szołtysek, J. (2018; 2019, 16 czerwca). Konflikt ładunki - ludzie w miastach. Refleksje logistyka. Konferencja „Miasto i Transport 2018”. Warszawa. Pozyskano z: http://www.miastoitransport. il.pw.edu.pl/mit_materialy.html

Użytkownicy hulajnóg przeciwni ograniczeniu prędkości. (2019, 16 lipca). Pozyskano z: https://www. ufg.pl/infoportal/faces/oracle/webcenter/portalapp/pagehierarchy/Page220.jspx?home=t\&_afrLoop $=47487260368258864 \&$ infid=182\&_afrWindowMode=08_adf.ctrl-state=w1hcg0wgj_154

W poszukiwaniu hulajnóg, czyli patrole hive Bees. (2019, 3 lipca). Pozyskano z: http://infobike.pl/w-poszukiwaniu-hulajnog-czyli-patrole-hive-bees_more_115551.html

Ziebura, J., Mazur, H. (2018; 2019, 28 lipca). Rowery towarowe w centrach miast. Konferencja „Miasto i Transport 2018". Warszawa. Pozyskano z: http://www.miastoitransport.il.pw.edu.pl/mit_materialy.html

Jerzy Janczewski, dr inż., adiunkt w Katedrze Systemów Transportowych Akademii Humanistyczno-Ekonomicznej w Łodzi. Autor jest inżynierem mechanikiem, doktorem nauk ekonomicznych w zakresie zarządzania. Jego zainteresowania badawcze koncentrują się na logistyce zwrotnej i problematyce zarządzania przedsiębiorstwami mikro- i małymi z branży usług motoryzacyjnych i transportu drogowego

Jerzy Janczewski, Eng. mechanic, DSc in economic sciences in management, University of $\mathrm{Hu}-$ manities and Economics in Lodz. His research interests focus on reverse logistics and management issues of micro- and small enterprises in automotive and road transport services

ORCID: https://orcid.org/0000-0002-6994-2683

\section{Adres/Address:}

Akademia Humanistyczno-Ekonomiczna w Łodzi

Wydział Techniki i Informatyki

Katedra Systemów Transportowych

ul. Rewolucji $1905 \mathrm{nr} 64$

90-222 Łódź, Polska

e-mail: jerzyjanczewski@poczta.onet.pl 